\title{
URGENSI KEBUTUHAN PEMBELAJARAN EKONOMI BERKARAKTER BERBASIS KELAS DI SMA
}

\author{
Endang Purwaningsih \\ Program Studi Pendidikan Ekonomi, Universitas Tanjungpura, Pontianak \\ E-mail: endang.purwaningsih@fkip.untan.ac.id
}

\begin{abstract}
This study aims to identify the need for developing class-based character-based economic teaching materials for high school students. This research is qualitative research with a case study research type. The research location is located in the city of Singkawang, with research informants involving eight economics teachers at the high school level, with data collection techniques in the form of focus group discussions. The data analysis of this research uses three activity lines that occur simultaneously, data reduction, data presentation, and conclusion drawing. The results of the study found that: (1) to date, there is no class-based character economy teaching material for high school students in the city of Singkawang; (2) It is necessary to develop classbased character-based economic teaching materials for high school students in the city of Singkawang.
\end{abstract}

Keywords: Economic learning, class-based, character

\begin{abstract}
Abstrak
Penelitian ini bertujuan untuk mengidentifikasi kebutuhan pengembangan bahan ajar ekonomi berkarakter berbasis kelas bagi peserta didik SMA. Penelitian ini adalah penelitian kualitatif dengan jenis penelitian studi kasus. Lokasi Penelitian ini terletak di Kota Singkawang, dengan informan penelitian yang melibatkan 8 guru ekonomi pada jenjang SMA, dengan teknik pengumpulan data berupa focus group discussion. Analisis data penelitian ini menggunakan tiga alur kegiatan yang terjadi secara bersamaan yaitu: reduksi data, penyajian data, penarikan kesimpulan. Hasil penelitian menemukan bahwa: (1) hingga saat ini belum ada bahan ajar ekonomi berkarakter berbasis kelas bagi siswa SMA di kota Singkawang; (2) Perlu dilakukan pengembangan bahan ajar ekonomi berkarakter berbasis kelas bagi siswa SMA di kota Singkawang.
\end{abstract}

Kata Kunci: Pembelajaran ekonomi, berbasis kelas, berkarakter

Hakekat pendidikan dimaknai sesuai dengan falsafah hidup yang dianutnya. Satya Sai memandang bahwa education without character are not only useless, but positively dangerous, the end of education is character (Biswal, 2014). Pendidikan tanpa karakter bukan hanya tidak berguna, tetapi sangat berbahaya. Karakter merupakan ruh-nya pendidikan. Undang-undang Tentang Sistem Pendidikan Nasional 
(UUSPN) Nomor 20 Tahun 2003 menempatkan nilai-nilai karakter sebagai ruh pendidikan. Hal ini terlihat dari makna pendidikan yang termuat dalam UUSPN sarat dengan nilai-nilai karakter luhur yang seharusnya menjadi bagian integral dalam pelaksanaan pendidikan. Namun, ada yang salah dalam implementasi UUSPN itu. Pendidikan dimaknai secara sempit yang lebih menekankan pada pembinaan, pengembangan potensi intelektual (kognitif) manusia serta mengabaikan proses pembentukan karakter melalui proses menyadari, menerima, menghayati, meyakini, mempribadikan dan mewujudkan nilai-nilai luhur menjadi karakter/akhlak mulia. Sehingga, pendidikan harus dikembalikan pada koridor yang benar yaitu mengembangkan ketiga potensi kognitif, afektif dan psikomotorik secara utuh dalam satu waktu (serempak) melalui suatu proses pembelajaran. Solusinya, Kurikulum 2013 revisi 2017 menetapkan aspek sikap (nilai-nilai karakter) sebagai aspek yang utama selain aspek kognitif maupun psikomotorik. Implementasi kurikulum ini sangat memerlukan adanya pendidikan karakter.

Karakter dalam pandangan (Sumatri, 2011: 3) adalah watak, tabiat, akhlak, atau kepribadian seseorang yang terbentuk dari hasil internalisasi berbagai kebajikan (virtues). (Lickona, 1991) merujuk pandangan filsuf Yunani Aristoteles mendefinisikan "good character as the life of right conduct-right conduct relation to other persons and in the relation to oneself'. Karakter yang baik dibentuk melalui internasisasi di dalam proses pendidikan karakter.

Pendidikan karakter menurut Lickona (Zubaedi, 2011) adalah usaha disengaja untuk mewujudkan kebajikan, yaitu kualitas kemanusiaan yang baik untuk individu maupun masyarakat. Pendidikan karakter dilaksanakan di dalam kelas melalui kegiatan pembelajaran. Pembelajaran adalah wahana yang didesain oleh guru secara sengaja untuk mencapai tujuan pendidikan. Pembelajaran dilaksanakan dalam kegiatan belajar mengajar yang mengarah pada upaya mencapai tujuan dalam bentuk perubahan perilaku dan kepribadian peserta didik. Perubahan peserta didik ditunjukkan dalam tampilan karakter, sebagai perilaku yang mencerminkan nilai-nilai luhur (Kemdikbud, 2019).

Pembelajaran yang mengintegrasikan nilai-nilai luhur dimaknai sebagai kegiatan pembelajaran berisi konten materi pelajaran yang diperlukan peserta didik untuk mencapai kompetensi akademiknya, sekaligus berisi nilainilai karakter luhur yang relevan untuk membentuk karakter baik (kebajikan). . Dalam pembelajaran berkarakter ini, pada satu waktu (waktu yang sama) berlangsung dua kegiatan sekaligus yaitu kegiatan untuk pencapaian kompetensi akademik dan pembentukan karakter yang baik. Pembelajaran pendidikan karakter itu tidak berlangsung terpisah dari pembelajaran yang dirancang menurut kurikulum. Tetapi, terintegrasi dalam kegiatan belajar peserta didik yang mempelajari materi untuk mencapai kompetensi akademiknya. Artinya, baik pencapaian kompetensi akademik maupun pembentukan kualitas 
karakter yang baik dilaksanakan secara holistik (utuh) pada satu waktu belajar.

Implementasi pembelajaran berkarakter sangat memerlukan kesiapan berbagai komponen pembelajaran terutama bahan ajar yang mengintegrasikan nilai-nilai karakter. Bahan ajar menurut Pannen (Prastowo, 2011) adalah bahan-bahan pembelajaran yang disusun secara sistematis, yang memudahkan guru dan peserta didik dalam melaksanakan kegiatan pembelajaran untuk mencapai tujuan pembelajaran. Bahan ajar itu menampilkan sosok utuh dari kompetensi yang akan dikuasi peserta didik (Prastowo, 2011). Bahan ajar secara substantif berisi pengetahuan (fakta, konsep, prinsip dan prosedur), keterampilan dan sikap atau nilai (Prastowo, 2011). Dalam pembelajaran berkarakter, bahan ajarnya berisi pengetahuan, keterampilan serta nilai-nilai yang relevan yaitu diambil dari 5 (lima) nilai utama Penguatan Pendidikan Karakter (religius, nasionalis, mandiri, gotong royong dan integritas).

Bahan ajar ekonomi berbasis karakter disesuaikan dengan tujuan mata pelajaran, kompetensi dasar, standar kompetensi serta kebutuhan peserta didik. Tujuan mata pelajaran ekonomi menurut Undang-undang Sistem Pendidikan Nasional Nomor 20 Tahun 2003 memuat aspek kognitif tentang sejumlah konsep ekonomi untuk mengaitkan dengan peristiwa dan masalah di lingkungan; aspek sikap ingin tahu terhadap berbagai konsep ekonomi disertai sikap bijak, rasional, bertanggung jawab atas pengetahuan dan keterampilan ekonomi. Sehingga, bahan ajar yang dikembangkan ini berisi tentang fakta, konsep, prinsip, prosedur (pengetahuan ekonomi), ketrampilan ekonomi serta lima nilai utama karakter.

Hasil wawancara kepada beberapa kepala sekolah maupun guru-guru ekonomi serta hasil pengamatan terhadap aktivitas pendidikan karakter atau Penguatan Pendidikan Karakter di 10 (sepuluh) SMA Negeri di Singkawang, menunjukkan bahwa guru-guru belum mengintegrasikan nilai-nilai utama karakter ke dalam konten materi pelajaran ekonomi. Hal ini bukan berarti pendidikan karakter sudah berhenti di jenjang SMP dan tidak berlanjut ke jenjang SMA. Akan tetapi, disebabkan karena lemahnya pemahaman guru tentang konsep pendidikan karakter mengakibatkan kesulitan memilih nilai karakter sesuai konten materi mata pelajaran (Ash-shidiqqi,2018). Kesulitan lainnya, belum tersedianya bahan ajar ekonomi yang praktis dan mudah untuk mengembangkan nilai-nilai utama pendidikan karakter. Bahan ajar ekonomi berkarakter dapat memberikan ruang dan pengalaman belajar bagi peserta didik untuk mencapai kompetensi akademik sekaligus membentuk kualitas karakternya. Bahan ajar ekonomi berkarakter diharapkan dapat membantu guru mencapai tujuan pendidikan dan pembelajaran yaitu kompetensi akademik dan kualitas karakater yang baik peserta didik. Penelitian (Purwaningsih, 2013) tentang model pembelajaran akuntansi berbasis nilai kejujuran yang menggunakan bahan ajar berkarakter dalam bentuk dilema moral akuntansi, membuktikan bahwa 
model tersebut efektif meningkatkan kompetensi akademik peserta didik sekaligus mampu meningkatkan karakter jujur dari sisi moral knowing kejujuran.

Berdasarkan hasil kajian di atas, maka kedudukan penelitian ini adalah berupaya menjawab permasalahan dalam implementasi pembelajaran ekonomi berkarakter, yakni menggali tentang kebutuhan bahan ajar ekonomi berkarakter yang relevan dan sangat dibutuhkan oleh sekolah-sekolah menengah atas di kota Singkawang.

\section{METODE}

Metode penelitian yang digunakan adalah penelitian kualitatif, mengingat permasalahan belum jelas, cenderung holistik, bersifat kompleks dan dinamis, serta penuh makna. Jenis penelitian ini adalah studi kasus, yang bermakna bahwa terdapat kekhususan fenomena dan obyek yang diteliti. Lokasi Penelitian ini terletak di Kota Singkawang, dengan informan penelitian yang melibatkan 8 (delapan) guru ekonomi pada jenjang SMA, dengan teknik pengumpulan data berupa focus group discussion. Analisis data penelitian ini menggunakan tiga alur kegiatan yang terjadi secara bersamaan yaitu: reduksi data, penyajian data, penarikan kesimpulan atau verifikasi (Miles, B. M. \& Huberman, 1992).

\section{HASIL DAN PEMBAHASAN}

Berdasarkan hasil focus group discussion dengan para guru di Kota Singkawang ditemukan beberapa hal berikut:

Guru telah menggunakan contoh kasus/peristiwa/perilaku lingkungan sekitar yang relevan dalam pembelajaran ekonomi, yang dimaksudkan: (1) untuk memudahkan peserta didik dalam memahami dan menerima pembelajaran ekonomi. (BDS; DSS; RN; WS; YR;JS;ASS); (2) agar peserta didik merasakan dan mengamati langsung sehingga membuat mereka lebih tertarik dan mudah mengikuti proses pembelajaran ekonomi. (BDS; ASS); (3) karena materi ekonomi sangat erat dengan kehidupan sehari-hari (RN). Terdapat pula guru yang belum menggunakan contoh kasus/peristiwa/perilaku lingkungan sekitar yang relevan dalam pembelajaran ekonomi, dikarenakan: (1) tidak semua dapat dijadikan contoh yang relevan dalam pelajaran ekonomi (SM); \& (2) terkadang ada materi ekonomi yang agak sulit diberikan contoh kasus/peristiwa/perilaku lingkungan sekitar yang relevan dengan materi tersebut (BDS)

Guru menuangkan contoh kasus/peristiwa/perilaku lingkungan sekitar yang terkait dengan konsepsi ekonomi telah dituangkan dalam bahan ajar berupa power point (BSS; $\mathrm{RN})$; adapula yang telah menuangkannya ke dalam RPP/perangkat pembelajaran (DSS, JS, YR WS,ASS). Terkait dengan menghadirkan peristiwa/perilaku lingkungan masyarakat sekitar yang terkait dengan konsepsi ekonomi ke dalam kelas, guru telah berusaha mengajak peserta didik untuk mencari contoh sederhana peristiwa dimasyarakat sekitar yang terkait konsepsi ekonomi (BDS; RN; WS; YR), adapula guru yang meminta peserta didik mencari data sebelum pembelajaran dimulai (SM; ASS). Upaya-upaya ini dimaksudkan agar 
peserta didik lebih mudah memahami materi jika peserta didik tersebut melihat langsung/ menelaah langsung kejadian disekitar. (WS)

Terdapat beberapa guru membawa peserta didik pada kejadian yang terkait dengan konsepsi Ekonomi, baik dengan kunjungan, maupun yang lain-lain. Pernah ada kunjungan sekolah ke PT. INDOFOOD, dan industri pengolahan Lidah buaya di Jl. 28 Oktober (JS; ASS). Adapula dengan memberikan penugasan kepada peserta didik melakukan kunjungan langsung ke dalam praktek pelaksanaan kegiatan ekonomi, misalnya dalam materi pasar, perbankan, indeks harga dan inflasi (peserta didik terjun langsung ke pasar untuk mengetahui perubahan harga barang) (BDS; WS). Adapula guru yang belum pernah membawa peserta didik pada kejadian yang terkait dengan konsepsi Ekonomi (YR;DSS;RN;SM), dengan alasan: (1) pertimbangan lokasi sekolah jauh dari sumber belajar yang dimaksud, serta pertimbangan lain (kendaraan, dan biaya) (DSS); (2) cukup dengan memberikan penugasan kepada peserta didik (SM)

Kemungkinan penempatan pembelajaran Ekonomi berdimensi penguatan pendidikan karakter berbasis kelas bagi peserta didik SMA di Kota Singkawang, kemungkinan dengan mekanisme memasukkan pembelajaran Ekonomi berdimensi penguatan pendidikan karakter ke dalam beberapa topik pembelajaran Ekonomi, sesuai kurikulum nasional (WS; SM; BDS; DSS; RN; YR; JS;ASS), yang diasumsikan bahwa hal tersebut akan menimbulkan pembiasaan pada anak, sehingga anak akan terbiasa mendengar dan menerapkan pendidikan karakter dalam pebelajaran ekonomi khususnya dan pada kehidupan bermasyarakat pada umumnya, sehingga diharapkan pendidikan karakter dapat melahirkan anak bangsa yang sesuai dengan yang kita harapkan dan menjadi penerus bangsa yang lebih baik. (BDS;DSS;RN). Adapun nilai-nilai penguatan pendidikan karakter yang biasa dibelajarkan kepada peserta didik antara lain: (1) kedisiplinan, dengan membuat perjanjian dalam pembelajaran, contoh tidak boleh mengaktifkan HP selama pembelajaran (SM; WS); (2) Jujur, peserta didik diberikan kesempatan menceritakan apa saja dalam kehidupannya mengenai kegiatan ekonomi (SM; RN; WS; JS; ASS); (3) kerjasama, saling bertukar pikiran dalam mendapatkan informasi (SM; RN; JS; ASS); (4) santun (WS); (5) komunikatif (RN); (6) peduli lingkungan (RN); (7) peduli sesama (WS); (8) tanggungjawab (WS); (9) mandiri (RN; YR; JS; ASS); (10) religius (BDS;DSS;RN;WS;ASS); (11) nasionalis/ mencintai tanah air (BDS; JS; ASS); (12) responsif (WS; JS); (13) sikap pro aktif (WS; JS); (14) toleransi (WS; JS); \& (15) integritas (JS; ASS).

Proses internalisasi kesadaran (penerimaan) tentang pentingnya kepedulian terhadap keadaan ekonomi teman dan/atau tetangga sekitar dapat dilakukan: (1) dengan memberikan gambaran berupa pengandaian atau bentuk gambar (JS; SM); (2) dengan mengajak langsung peserta didik menolong teman yang sedang tertimpa musibah ( $\mathrm{RN})$; (3) dengan mengajak membantu teman atau tetangga yang kurang mampu dalam 
perekonomian (BDS; DSS; WS; YR; ASS). Sementara proses internalisasi kesadaran (penerimaan) tentang pentingnya memperhatikan dampak perilaku ekonomi terhadap orang lain dapat dilakukan dengan: mengingatkan peserta didik yang memiliki tingkat ekonomi ke atas untuk lebih menghargai temannya yang kurang mampu secara ekonomi, agar mereka berpenampilan dan menggunakan fasilitas yang mereka gunakan ke sekolah secara tidak berlebihan layaknya seorang peserta didik (BDS); \& (2) dengan mengajarkan peserta didik agar hidup hemat dan tidak boros (DSS; YR). Adapun proses internalisasi kesadaran (penerimaan) tentang pentingnya memperhatikan nilai-nilai RELIGIUS dalam berperilaku ekonomi dapat dilakukan dengan: (1) menyelipkan pesan pada saat proses pembelajaran untuk selalu bersyukur terhadap apa yang telah dimiliki dan mensyukuri SDA yang berlimpah yang bisa kita manfaatkan (BDS; DSS); (2) melalui pesan yang disampaikan dalam pembukaan dan penutup pembelajaran berupa berlaku jujur saat melakukan transaksi jual beli (RN; YR).

Proses internalisasi kesadaran (penerimaan) tentang pentingnya memperhatikan nilai-nilai NASIONALIS dalam berperilaku ekonomi, misalnya untuk membeli produk-produk dalam negeri dapat dilakukan dengan: (1) pengenalan produk lokal melalui materi pelajaran (BDS; JS); (2) dengan menganjurkan peserta didik memproduksi barang yang bernilai budaya (DSS;YR); (3) dengan mengajak peserta didik menggunakan produk lokal dan khas di momen tertentu saat di sekolah
(ASS). Sementara proses internalisasi kesadaran (penerimaan) tentang pentingnya memperhatikan nilai-nilai KEMANDIRIAN dalam berperilaku ekonomi, misalnya untuk membiasakan mengatur keuangan, termasuk berkonsumsi secara hemat dan menabung dapat dilakukan dengan: (1) mengarahkan peserta didik untuk melakukan pencatatan keuangannya serta membuat skala prioritas (SM; BDS; DSS; YR); (2) mengarahkan peserta didik untuk menyisihkan uang jajannya serta mengarahkan peserta didik agar mengelola uang jajan tersebut sebagai modal atau hanya sebagai simpanan (JS;ASS)

Proses internalisasi kesadaran (penerimaan) tentang pentingnya memperhatikan nilai-nilai GORONG ROYONG dalam berperilaku ekonomi, misalnya menyampaikan tentang pentingnya bekerjasama dalam perekonomian, dan/atau menyampaikan contoh budaya lokal gotong royong dapat dilakukan dengan: (1) penjelasan berupa contoh kegiatan gotongroyong yang dekat dengan kehidupan peserta didik saat pelajaran ekonomi (SM; BDS; RN; JS); (2) memberikan penugasan agar peserta didik bisa mempraktekkan kegiatan gotong royong di sekolah dan di lingkungan sekitar (YR; ASS). Adapun proses internalisasi kesadaran (penerimaan) tentang pentingnya memperhatikan nilai-nilai INTEGRITAS dalam berperilaku ekonomi, misalnya untuk membiasakan berperilaku jujur saat berbelanja di kantin, dapat dilakukan dengan: (1) membangun kantin kejujuran di sekolah (RN); (2) dengan membiasakann peserta didik untuk mengungkapkan sesuatu secara jujur 
dan melalui penugasan yang harus mereka kumpulkan tepat waktu (BDS; DSS).

$$
\text { Adapun }
$$

contoh

kasus/peristiwa/perilaku ekonomi berkarakter yang relevan dengan konsepsi Ekonomi yang ada di Kota Singkawang \& sekitarnya, berhubungan dengan: (1) image Singkawang yang dikenal dengan kota pariwisata yang menuntut peserta didik untuk menjaga kota Singkawang agar tetap nyaman (BDS); (2) perayaan keagamaan, adat dan budaya tahunan di Singkawang yang mencerminkan toleransi dan dapat meningkatkan perekonomian masyarakat. (BDS; DSS; RN; YR; ASS); (3) kegiatan ekonomi yang berjalan rutin berupa pasar Hongkong setiap harinya mencerminkan sikap saling menghargai antar pedagang (JS; WS). Sementara Budaya yang menunjukkan budaya ekonomi berkarakter (mengandung nilai-nilai religius, nasionalis, mandiri, gorong royong dan integritas) yang ada di Kota Singkawang \& sekitarnya antara lain; (1) Perayaan Cap Go Meh di Kota singkawang, dicerminkan melalui toleransi beragama, para masyarakat yang merayakan akan berhenti sejenak saat umat muslim melakukan ibadah (RN); (2) Budaya Balalek, merupakan kegiatan gotong royong bergiliran saat musim tanam dan panen padi. Budaya ini masih bisa ditemukan di wilayah pinggiran kota. (JS).

Berdasarkan berbagai uraian yang disampaikan para guru dalam FGD, dapat disimpulkan bahwa telah ada guru yang mengintegrasikan nilai-nilai utama karakter ke dalam materi pembelajaran ekonomi. Namun, integrasi nilai-nilai utama karakter masih bersifat insidentil dan belum terprogram, disebabkan karena belum tersedia bahan ajar ekonomi berbasis karakter. Melalui diskusi terfokus itu para guru melihat adanya urgensi kebutuhan bahan ajar ekonomi berkarakter saat ini. Sehingga, para guru mengusulkan adanya pengembangan bahan ajar Ekonomi berdimensi penguatan pendidikan karakter bagi peserta didik SMA, yang sekaligus dapat memudahkan peserta didik dalam memahami isi pelajaran.

\section{Konsep Karakter dan Pendidikan Karakter}

Karakter menyangkut ciri kepribadian seseorang. Budimansyah, (2018) memandang karakter sebagai nilai-nilai khas baik (tahu nilai kebaikan, mau berbuat baik, nyata berkehidupan baik, dan berdampak baik terhadap lingkungan). Pandangan ini sejalan dengan (Lickona, 1991) bahwa, Character so conceived has three interrelated parts: moral knowing, moral feeling, and moral behaviour. Good character consists of knowing the good, desiring the good, and doing the good-habits of the mind, habits of the heart, and habits of action. Berdasarkan definisi diatas dapat ditarik kesimpulan bahwa karakter merupakan nilai-nilai kebaikan (tahu nilai kebaikan/moral knowing, mau berbuat baik/moral feeling, dan nyata berkehidupan baik/moral acting) yang terpateri secara mapan (personalized) dalam diri dan terwujud dalam perilaku.

Pendidikan karakter di Indonesia menetapkan bahwa, nilainilai utama karakter yang ditanamkan dan dikembangkan pada peserta didik mencakup 5 (lima) nilai utama 
Pancasila yaitu nilai religius, nasionalis, mandiri, gotomg royong dan integritas. Kelima nilai utama pendidikan karakter yang merupakan kristalisasi dari 18 nilai karkater yaitu nilai religius, jujur, toleransi, disiplin, kerja keras, kreatif, mandiri, demokratis, rasa ingin tahu, semangat kebangsaan, cinta tanah air, menghargai prestasi, bersahabat komunikatif, cinta damai, gemar membaca, peduli lingkungan, peduli soaial, tanggung jawab dan lain-lain.

Pendidikan karkater menurut Lickona Character education is the deliberate effort to cultivate virtue that is objectively good human qualities that are good for the individual person and good for the whole society (Lickona, 1991). Pendidikan karakter adalah usaha sengaja (sadar) untuk mewujudkan kebajikan, yaitu kualitas kemanusiaan yang baik secara obyektif, bukan hanya baik untuk individu perorangan, tetapi juga baik untuk masyarakat secara keseluruhan. Dalam pandangan Lickona, kualitas kemanusiaan (kebajikan) yang dikembangkan melalui pendidikan karakter tidak hanya yang menyangkut diri sendiri (seperti kontrol diri, disiplin, tanggung jawab), namun termasuk yang berkaitan dengan orang lain/masyarakat (murah hati, empati).

\section{Bahan Ajar Ekonomi Berkarakter}

Bahan ajar merupakan komponen pembelajaran yang sangat penting dalam melaksanakan proses pembelajaran, yang mencakup semua bahan dan sumber daya yang dapat digunakan oleh guru untuk mengembangkan pengetahuan, keterampilan, sikap dan nilai peserta didik. Bahan ajar mempunyai peran penting dalam mencapai proses pembelajaran yang efisien. Bahan ajar menyajikan penjelasan-penjelasan serta tanda-tanda yang memudahkan peserta didik memahami materi. Menurut Dick, W. and Carrey, (1985) bahan merupakan seperangkat materi/substansi pelajaran (teaching material) yang disusun secara sistematis, menampilkan sosok utuh dari kompetensi yang akan dikuasai oleh pesert didik dalam kegiatan pembelajaran. Berdasarkan pendapat ahli tersebut, bahan ajar adalah seperangkat/semua materi pembelajaran yang disusun secara sistematis yang dapat digunakan oleh guru untuk mengembangkan pengetahuan, keterampilan, sikap dan nilai yang menampilkan sosok utuh kompetensi yang akan dikuasai peserta didik.

Materi pelajaran yang disusun dalam bahan ajar memberikan kemudahan guru untuk menyampaikan pesan pengetahuan kepada peserta didik secara akurat, tepat, jelas dan mudah dimengerti. Bahan ajar menyederhanakan pengetahuan abstrak menjadi lebih konkrit, sehingga memungkinkan peserta didik memahami ide-ide yang kompleks (Saglam, 2011). Studi menyimpulkan bahwa semakin tinggi jumlah pancaindera yang diaktifkan oleh bahan ajar yang digunakan dalam proses pembelajaran, maka proses belajar semakin baik dan lebih tahan lama (Saglam, 2011).

Dalam memilih bahan ajar yang baik tentu perlu mempertimbangkan karakteristik peserta didik serta kebutuhannya untuk mencapai kompetensi yang yang telah ditentukan. Saglam (2011) 
menekankan bahwa, bahan ajar yang layak dipilih dalam proses pembelajaran adalah yang membuat pembelajaran itu mudah dan bertahan lama, menyederhanakan informasi abstrak menjadi konkrit, meningkatkan motivasi, menyederhanakan informasi yang kompleks sehingga mudah dimengerti.

Karakter adalah akumulasi nilai-nilai kebaikan yang merupakan hasil internalisasi nilai-nilai melalui proses pendidikan karakter. Karakter yang baik itu adalah tahu nilai kebaikan, mau berbuat baik dan melakukan perbuatan baik. Untuk membentuk peserta didik yang tahu nilai kebaikan (moral knowing) pendidik dapat melakukan upaya penanaman nilai karakter baik melalui penjelasan-penjelasan tentang konsep karakter yang baik. Guru juga dapat menggunakan kasus dilema moral sesuai dengan teori Perkembangan Moral Kohlberg. Diskusi dilema moral dapat mengasah pertimbangan moral peserta didik.

Komponen karakter moral feeling adalah keyakinan atau kemauan untuk berbuat baik yang dapat menjembatani terwujudnya perbuatan baik. Nilai-nilai kebaikan (karakter yang baik) dapat diinternalisasikan ke dalam diri seseorang dengan menggunakan contoh (Arjoon, 2002). Karakter yang baik dapat ditanamkan melalui tindakan (Sockett, 1996). Teori yang relevan dengan pandangan di atas adalah teori "Social Learning" Albert Bandura (1963). Menurut teori ini, belajar itu dilakukan melalui imitasi atau meniru. Imitasi merupakan teknik pengembangan perilaku individu dengan meniru dari apa yang ditafsirkannya melalui observasi terhadap suatu model yang menjadi objek observasinya (Bandura, 1963). Model merupakan figur yang menjadi panutan perilaku peserta didik. Guru atau figur lain yang ada dalam contoh peristiwa dapat menjadi model perilaku. Pandangan ini sesuai dengan konsep karakter (Lickona, 1991) bahwa karakter terdiri dari nilai operasi, nilai dalam tindakan.

Beberapa pandangan ini memberikan implikasi bahwa pendidik yang menginginkan peserta didiknya bertindak jujur, peduli, toleran, gotong royong perlu memberikan pemahaman tentang konsep nilai-nilai karakter baik tersebut yang diintegrasikan dalam materi pembelajaran ekonomi misalnya. Guru juga dapat menumbuhkan keinginan untuk berbuat jujur, peduli, toleran, gotong royong melalui pengkajian contohcontoh perilaku dikaitkan dengan materi ekonomi untuk mengundang dan melibatkan pikiran dan perasaan peserta didik. Selanjutnya, inti dari internalisasi karakter, guru mendorong peserta didik untuk mempraktekkan nilai-nilai karakter baik ke dalam kegiatan ko-kurikuler misalnya. Peserta didik dapat memperoleh dan memperkuat keinginan mereka untuk jujur jika melihat sifat kejujuran gurunya yang didukung oleh keinginan untuk meniru guru. Persepsi siswa tentang gurunya sebagai seseorang yang jujur cenderung memperkuat keinginannya untuk menjalani kehidupan yang jujur (Aboluwodi, Ph.D \& Akinsanoye, 2019). Aristoteles menegaskan bahwa internalisasi karakter tidak akan berhasil bila hanya memberikan pemahaman tentang konsep-konsep 
nilai kebaikan, namun harus memberikan pengalaman dan pembiasaan peserta didik untuk mempraktekkan karakter baik dalam bentuk perbuatan nyata (Sockett, 1996).

Dalam silabus mata pelajaran Ekonomi kelas X, XI, XII terdapat KI-KD yang dapat dintegrasikan lima nilai utama pendidikan karakter dalam materi pembelajarannya. Seperti pada materi "Kelangkaan" relevan untuk menginternalisasikan nilai peduli, jujur, tolong menolong atau gotong royong. Pada materi "Pajak" juga bisa menjadi media untuk menginternalisasikan nilai tanggung jawab, jujur, cinta tanah air. Selain beberpa contoh tersebut, masih banyak materi Ekonomi yang dapat menjadi media pengembangan karakter peserta didik. Untuk mengimplementasikan aktivitas pendidikan karakter dalam pembelajaran Ekonomi sangat memerlukan dukungan bahan ajar yang berbasis karakter.

\section{SIMPULAN DAN SARAN Simpulan}

Berdasarkan temuan penelitian di atas, dapat disimpulkan bahwa: (1) Hingga saat ini belum ada bahan ajar ekonomi berkarakter berbasis kelas bagi siswa SMA di kota Singkawang; (2) Perlu dilakukan pengembangan bahan ajar ekonomi berkarakter berbasis kelas bagi siswa SMA di kota Singkawang.

\section{Saran}

Dalam upaya membelajarkan bahan ajar ekonomi berkarakter berbasis kelas bagi siswa SMA di kota Singkawang, perlu dipersiapkan: (1) fasilitas pendukung pelaksanaan pembelajaran; \& (2) sosialisasi pentingnya pembelajaran ekonomi berkarakter, dalam rangka membentuk karakter positif peserta didik untuk berperilaku moral ekonomi.

\section{DAFTAR RUJUKAN}

Aboluwodi, Ph.D, A., \& Akinsanoye, K. E. (2019). Character Education and Virtue Ethics in Nigerian Schools. Journal of Education, Teaching and Social Studies, $\quad 1(1), \quad 1$. https://doi.org/10.22158/jetss.v1 n1p1

Anugerah Ash-shidiqqi, E. (2018). the Analysis of Character Education in Indonesia. International Journal of Humanities, Art and Social Studies (IJHAS), 3(4), 39-46.

Arjoon, S. (2002). Moral Development: a Case for Character Education. 868.

Bandura, A. (1963). Social reinforcement and behavior change-Symposium, 1962: 1. Behavior theory and identificatory learning. In American Journal of Orthopsychiatry (Vol. 33, Issue 4, pp. 591-601). https://doi.org/10.1111/j.19390025.1963.tb01007.x

Dick, Walter and Carrey, L. (1985). The Systematic Design Of Instruction. Scott, Foresman and Company.

Kemdikbud. (2019). Model Penilaian Karakter. 1-59.

Lickona, T. (1991). Educating For Character How Our Shcools Can Teach Respect and Responsibility (- (ed.); First). 
Bantam Books.

Miles, B. M. \& Huberman, M. (1992). Analisis Data Kualitatif Buku Sumber Tentang Metodemetode Baru. UIP.

NARAYAN BISWAL， B. (2014).

Noble Ideas of Swami

Vivekananda on Education and in globle Intentions of Lord Macaulay: a Critical Review on School Education in India. Issues and Ideas in Education, 2(2), 149-157. https://doi.org/10.15415/iie.2014 .22011

Prastowo, A. (2011). Bahan Ajar Inovatif. Diva Press.

Prof. Dr. Dasim Budimansyah, M. S. (2018).

Perancangan

Pembelajaran Berbasis Karakter (Dr. Rahmat (ed.); Pertama). Widya Aksara Press.

Purwaningsih, E. (2013). Pengembangan Model Pembelajaran Akuntansi Berbasis Nilai Kejujuran Studi Pada SMK Negeri 3 Pontianak. reprository.upi.edu.
Saglam, H. I. (2011). An investigation on teaching materials used in social studies. Turkish Online Journal of Educational Technology, 10(1), 36-44.

Sockett, H. (1996). Can virtue be taught? Educational Forum, 60(2), 124-129. https://doi.org/10.1080/0013172 9609335113

Sumatri, E. (2011). Pendidikan Budaya dan Karakter Suatu Keniscayaan bagi Kesatuan dan Persatuan Bangsa. dalam Pendidikan Karakter: Nilai Inti Bagi Upaya Pembinaan Kepribadian Bangsa. Widya Aksara Press.

Zubaedi. (2011). Desain Pendidikan Karakter (Kseatu). Kencana Prenada Media Grup. 